\title{
水質污濁物質削減を考慮した水利用負担金の 効果的な運用に関する研究
}

韓国八堂 (パルダン) 湖におけるシミュレーション——

金 真 朱*, 水 鉋 揚四郎*

\section{1. 研究の背景と目的}

韓国の八堂湖は漢江の下流部に位置するダム型湖沼である。現在は韓国の首都ソウル及びソウ ル周辺の首都圈の住民に水を供給する水源として機能している。政府は八堂上水源の水質を改善 するため, 水利用負担金制度を実施した。しかし，八堂湖の水質改善の兆しは見えていない。し かも, 政府からの規制により, 経済的活動を制限されてきた八堂湖の周辺地域では, 不満が高まっ ている。そこで，水利用負担金制度を実施する上で，効果的運用の方法が求められてきた。水利 用負担金の運用に関しては, 効果的な配分に関する研究として, ソンミヨン (2000) [6] の先行研 究がある。その内容は，具体的な水利用負担金の配分方法を提示することではなく，アンケート を通じて水利用負担金の適切な水準を見出す調査にとどまっている。本研究と同種のモデルによ る研究がいくつかある。まず, 水鉋 (1984) [8] は水質改善のための総合評価モデルとしての基本 的なモデルを構築している。Higano (1997) [11] は環境政策での提案に関する方向性を提示した 論文で，広瀬 (2001) [9] では閉鎖性水域の水質改善政策として社会経済モデル，エコシステムモ デルを構築し，社会的活動と水質污濁の問題を取り扱っている。水野谷 (2002) [10]では霞ヶ浦 の水質改善のために污濁負荷削減技術の評価と最適環境政策に関する研究を行った。しかし, こ れらの研究は日本における環境政策を想定し，シミュレーションを行ったものであり，韓国で実 施されている水利用負担金制度を取り入れて水質改善政策を評価分析した研究はない。そこで, 本 研究では, 韓国の八堂湖を研究対象地域とし, 社会経済, 污濁物質モデルを構築することで, 韓 国での現在実施されている政策を導入する。そして，現在行われている水質改善政策である水利 用負担金制度をモデルとして構築し，効果的な運用を提案することを目的とし，その有効性を検 討する。

* 筑波大学大学院生命環境科学研究科 


\section{1 研究対象}

\subsection{1 八堂湖の水資源の現状}

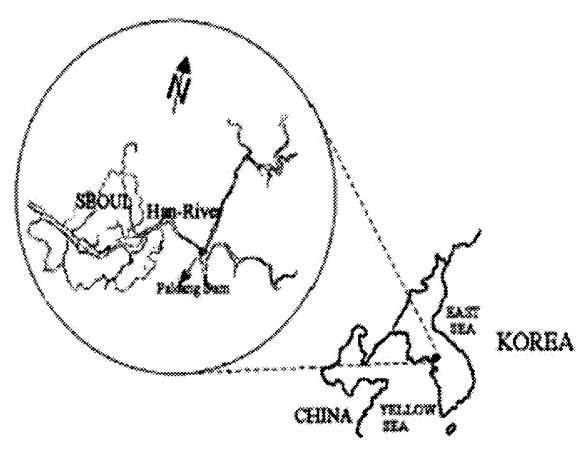

図 1 八堂湖の位置 [12]

韓国は流域に基づき 4 つ圈域に分けることができる。八堂湖は 4 つ圈域の中でも水量, 人 口，下水道普及率において，最も大きい圏域である漢江圏域に属している。漢江水系の中心とな る八堂湖は，ソウルの東側に位置している。八堂湖の上流では南漢江，北漢江，慶安川に分かれ ており，八堂湖はこれら 3 つの河川の合流地点にある。[3]

\subsection{2 水利用負担金}

水利用負担金の導入に至った背景には，政府の水質改善政策の実施により生じた上水源地域へ の規制に相応する地域住民に対する支援が足りなかったことがある。八堂湖周辺地域は，1975 年 に上水源保護区域，1990 年に特別対策地域として指定され，様々な経済活動行為が制限された。 1999 年には河川両岸の $500 \mathrm{~m} \sim 1 \mathrm{~km}$ 以内の土地が周辺地域として指定された。これらは主に土 地利用や産業への制限である。水利用負担金は，八堂湖及び漢江本流から取水された原水が直接 的・間接的に供給されるソウル，仁川，京畿道の 22 の市郡*地域の最終需要者が水使用量に比例 し一定額を納入し, 基金として集めた財源に基づいている。水利用負担金は水の最終需要者に上・ 下水道費とは別に上乗せされ，徵収されることになっている。[1]

\section{2 研究手法}

本研究では, 研究対象地域における自然環境, 社会環境を簡略化したモデルを構築し, 産業連 関表（韓国銀行（2003））［2］を用いて，線形計画法に基づいた最適化シミュレーションを行う。 シミュレーションでは, 八堂湖周辺地域の地域内総生産の最大化及び削減可能な污濁物質量 $(\mathrm{T}-$ $\mathrm{N}, \mathrm{T}-\mathrm{P}, \mathrm{COD})$ の導出を目的とする。10 年間を動学化し， 1 年を 1 期とすることで，10 年間の 変化を見る。污濁物質量は污染源別に生活系, 面源系, 生産系に分類する。生活系は下水処理施

* 韓国の市郡は日本の市町村にあたる 
設別人口に, 面源系は土地利用別面積に, 生産系は産業別総生産額の 2001 年データ(環境部(1998) [1]，漢江流域環境庁 (2001) [3]，江原道 (2001) [4]，京畿道 (2001）［5]，忠淸北道 (2001) [7]） に基づき算出し，現状を把握する。政策としては空間的及び対策的提案をすることで，研究対象 地域の経済を発展させながら，達成可能な污濁物質量值を探し，提案した政策の有効性を考察す る。

\section{2. モ デル 分 析}

\section{1 政策提案}

\subsection{1 空間的提案}

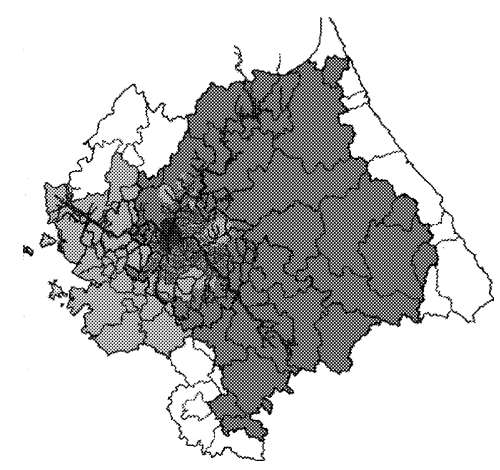

図 2 水利用負担金の地域現状 [13]

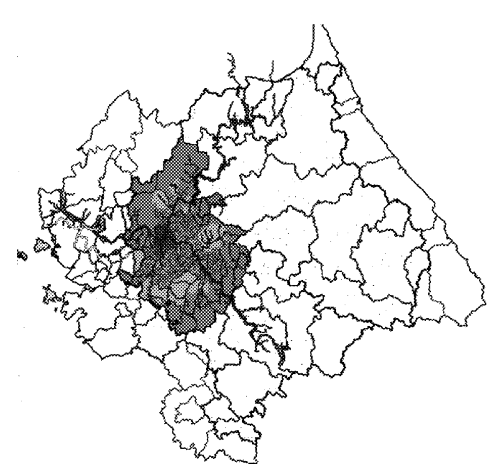

図 3 研究対象地域

本研究では, 効率的な污濁物質の削減及び規制地域住民の不満を解消するために, 水利用負担 金が配分される地域を規制地域及び周辺地域に限定する。

\subsection{2 対策的提案}

生活系では環境基礎施設の設置，運営費を補助する。面源系では土地を買収し，水田や畑を雑 種地に，雑種地を市街地に変化させる。生産系においては，現状では規制地域で各産業に制限が あるだけで，補償はなされていないが，本研究では，すでに規制がかかる地域には，産業にも補 助金を与えることにする（図 3 の色が塗られた部分）。

表 1 研究対象地域の流域及び市郡コード

\begin{tabular}{|c|c|c|c|}
\hline コード & 流 域 & コード & 市 \\
\hline 1 & 南漢江 & $1 \sim 16$ & $\begin{array}{l}\text { 光州市, 利川市, 安城市, 驪州郡, 楊平郡, 忠州市, 堤川市, 槐山郡, 陰城郡, } \\
\text { 丹陽郡, 原州市, 横城郡, 寧越郡, 平昌郡, 㫋善郡, 龍仁市 }\end{array}$ \\
\hline 2 & 北漢江 & $1 \sim 9$ & $\begin{array}{l}\text { 南楊州市，抱川市，加平郡，春川市，洪川郡，鐵原郡，華川郡，楊口郡， } \\
\text { 蹄郡 }\end{array}$ \\
\hline 3 & $\begin{array}{c}\text { 漢江本流 } \\
\text { 及び慶安川 }\end{array}$ & $1 \sim 6$ & 河南市，東豆川市，九里市，坡州市，楊州市，漣川郡 \\
\hline
\end{tabular}


表 2 污濁物質発生源別 フレーム

\begin{tabular}{|c|c|c|c|c|c|}
\hline コード & 下水処理施設 & コード & 土地利用 & コード & 産業 \\
\hline 1 & 下水道 & 1 & 農地（水田） & 1 & 農業 \\
\hline 2 & マウル下水道 & 2 & 農地（畑） & 2 & 畜産業 \\
\hline 3 & 合併浄化槽 & 3 & 山林 & 3 & 水産業 \\
\hline 4 & 単独浄化槽 & 4 & 市街地 & 4 & 製造業 \\
\hline 5 & 污水浄化処理 & 5 & 雑種地 & 5 & その他の産業 \\
\hline 6 & 未処理 & & & & \\
\hline
\end{tabular}

\section{2 モデル}

\subsection{1 污濁負荷モデル}

各流域から排出される污濁物質は, 各下水処理施設から河川を通って, 八堂湖に流れると仮定 する。

$$
Q(t)=\sum_{j} a_{j}(t)+Q^{F}(t)+Q^{R}(t)
$$

$Q(t)$ : 八堂湖へ流入する総污濁物質量 $\quad a_{j}(t)$ : 各流域から発生する污濁物質量 $Q^{F}(t)$ : 水産業加らの污濁物質量 $Q^{R}(t)$ : 湖面降雨による污濁物質量 $t$ : 時間

$$
a_{j}(t)=k_{j} r_{j}(t)
$$

$k_{j}:$ 河川の流達率 $\quad r_{j}(t)$ : 各流域からの污濁負荷量

（1） 各流域からの污濁負荷量

污濁物質発生源別に生活系, 生産系, 面源系に分ける。

$$
r_{j}(t)=Q^{H}(t)+Q^{L}(t)+Q^{I}(t)
$$

$Q^{H}(t)$ : 生活系からの排出污濁物質量 $Q^{L}(t)$ : 面源系からの排出污濁物質量 $Q^{I}(t)$ : 生産系からの排出污濁物質量

（2）生活系からの污濁負荷量

生活系からの污濁物質による負荷量は人口に比例し, 排出される。ここでは下水道, マウル下 水道 ${ }^{\dagger}$, 合併浄化槽を増やすことを対策として考える。

$$
Q^{H}(t)=E^{k} Z_{i}(t)
$$

$E^{k}$ : 生活系污濁排出係数 $Z_{i}(t)$ : 各市郡別の生活排水処理形態別人口 人口

$$
Z_{i}(t)=\sum_{k} P T_{i}^{k}(t)
$$

\footnotetext{
† 韓国のマウル下水道は日本の農業集落排水にあたる
} 
$Z_{i}(t)$ ：ある年の人口 $P T_{i}^{k}(t)$ ：ある年の下水処理施設別使用人口

各下水処理施設の使用人口変化

$$
\begin{gathered}
Z_{i}(t+1)=\left(1+\eta_{i}\right) \sum P T_{i}^{k}(t) \\
P T_{i}^{k}(t+1)=P T_{i}^{k}(t) \pm \Delta P_{i}^{k}(t)
\end{gathered}
$$

$Z_{i}(t+1)$ : 翌年の人口 $\quad \eta_{i}$ : 人口増加率 $\Delta P_{i}^{k}(t)$ : 各下水処理施設の使用人口変化 市郡の財政

$$
R_{i}(t)=\rho_{i} P_{i}(t)
$$

$R_{i}(t)$ : 財政規模 $\rho_{i}$ : 住民 1 人あたりの財政規模（歳出額）

財政制約

$$
b_{i}^{1}(t)+b_{i}^{2}(t)+b_{i}^{3}(t)+g_{i}^{1}(t)+g_{i}^{2}(t) \leq \omega R_{i}(t)+\left(\Theta^{\prime}+\Theta^{\prime \prime}+\Theta^{\prime \prime \prime}\right) T W(t)
$$

$b_{i}^{k}$ : 下水処理施設の設置補助費 (上添字 $\left.k=1,2,3\right) \quad \omega$ : 生活排水対策比率

$g_{i}^{k}$ : 下水処理施設の維持補助費 (上添字 $\left.k=1,2\right) \quad T W(t)$ : 水利用負担金

下水処理施設維持・運営費

$$
M C_{i}^{k}(t)=v_{i} P T_{i}^{k}(t)
$$

$M C_{i}^{k}(t)$ : 下水処理施設維持・運営費 $\quad v_{i}$ : 下水処理施設使用 1 人あたり維持・運営費

$$
M C_{i}^{k}(t) \leq g_{i}^{k}(t)+\Theta^{\prime} T W(t)
$$

$g_{i}^{k}(t):$ 市郡からの下水処理施設の維持・運営補助

$\Theta^{\prime}:$ 水利用負担金での下水処理施設維持・運営費への配分比率

施設使用人口変化

$$
\Delta P_{i}^{k}(t) \leq \Gamma_{i}^{k} i_{i}^{k}(t)
$$

$\Gamma_{i}^{k}$ : 投資額あたり増加人口 $\quad i_{i}^{k}(t)$ : 建設投資額 建設投資額

$$
i_{i}^{k}(t)=\left(\frac{1}{1-M_{i}^{k}(t)}\right) \Theta^{\prime \prime} T W(t)
$$

$M_{i}^{k}(t)$ : 市郡による補助比率 $\Theta^{\prime \prime}$ : 水利用負担金での下水処理基礎施設建設への配分比率 合併処理浄化槽設置補助

$$
\delta \Delta P_{i}^{3}(t)=\left(\frac{1}{1-M_{i}^{3}(t)}\right) \Theta^{\prime \prime \prime} T W(t)
$$

$\delta: 1$ 人あたり合併処理浄化槽設置費 $\quad M_{i}^{3}(t)$ : 市郡からの設置補助比率

$\Theta^{\prime \prime \prime}:$ 水利用負担金加合併処理浄化槽への配分比率 
（3）面源系による污濁物質の総負荷量

土地利用に対する対策としては土地買収により污濁物質負荷量を減らすことにする。 土地利用による総污濁物質量

$$
Q^{L}(t)=G^{g} L_{j}(t)
$$

$G^{g}$ : 面源系污濁排出係数 $L_{j}(t)$ : 土地利用面積

土地利用

$$
\begin{gathered}
\overline{L_{j}}=\sum_{g=1}^{5} L_{j}^{g}(t) \\
L_{j}(t+1)=L_{j}(t) \pm \Delta L_{j}(t)
\end{gathered}
$$

$\overline{L_{j}}$ : 流域面積 $L_{j}^{g}(t)$ : 土地利用 $g$ の面積

$L_{j}(t)$ : ある年の土地利用 $\Delta L_{j}(t)$ : 土地利用変化の面積

土地利用変化

$$
\Delta L_{j}(t)=\sum_{b \neq d} L_{j}^{d b}(t)-\sum_{d \neq b} L_{j}^{b d}(t)
$$

$L_{j}^{d b, b d}(t)$ : 土地利用 $b$ から $d(d$ から $b)$ への変化

污濁物質の排出が大きい農地（水田，畑）は，比較的に污濁物質の排出が少ない雑種地へと変 換させる。雑種地は, 人口変化や産業構図の変化を考慮し, 市街地に変わるとする。土地面積は 変化せず，山林の面積も変わらないとする。 土地利用変化への補助金

$$
L_{j}(t) \geq \lambda S_{j}^{m}(t)
$$

$\lambda$ : 農地削減量一補助金支給比率パラメータ

（4）生産系からの污濁物質の総負荷量

産業からの污濁物質の総負荷量は各産業の生産額に比例すると仮定する。

$$
Q^{I}(t)=P^{n} x_{i}(t)
$$

$P^{n}$ : 生産系污濁排出係数 $\quad x_{i}(t)$ : 各産業の生産額 生産制約

$$
x_{i}^{n}(t) \leq \alpha^{n} K_{i}^{n}(t)
$$

$\alpha^{n}:$ 生産制約係数 $\quad K_{i}^{n}(t)$ : 各市郡での各産業の資本ストック 資本蓄積及び生産額調整

資本蓄積による動学化を表現するために，資本は生産額に応じて増えるとみなす。減価償却に より資本は減少し，投資により増加するとみなす。ここで各産業に補助金を与えて資本を減少さ せることで, 生産額を調整し, 污濁負荷を削減すると考える。 


$$
K_{i}^{n}(t+1)=\left(1-d^{n}\right) K_{i}^{n}(t)+i_{i}^{n}(t)-s_{j}^{m}
$$

$K_{i}^{n}(t)$ : 各産業の生産資本蓄積 $i_{i}^{n}(t)$ : 各産業の生産投資

$d^{n}$ : 各産業の減価償却率 $\quad s_{j}^{m}$ : 各産業に対する補助金

（5）水産業による污濁物質の総負荷量

$$
Q^{F}(t)=P^{3} x^{3}(t)
$$

$Q^{F}(t)$ : 水産業からの污濁物質量 $P^{3}$ : 水産業污濁排出係数 ${ }^{\ddagger} \quad x^{3}(t)$ : 水産業の生産額

（6）湖面降雨による污濁物質の総負荷量

$$
Q^{R}(t)=\phi P L_{l}
$$

$Q^{R}(t)$ : 湖面降雨による污濁物質量 $\quad \phi$ : 降雨污濁負荷係数 $\quad P L_{l}$ : 湖面積

\subsection{2 財政モデル}

八堂湖周辺地域に配分される環境基礎施設の設置及び運営に関する補助金は全額を水利用負担 金から賄うことにする。

（1）水利用負担金の助成

水利用負担金は八堂湖を水源として水を供給されている地域から 1 トン当たり 11 円を払って もらい，それを財源とすることで政策を実施する。

$$
T W(t)=U W(t) \times 11 \text { Yen/ton }
$$

$T W(t)$ : 水利用負担金 $U W(t)$ : 水利用負担金負担地域の 1 年間の水使用量

$$
U W(t+1)=\xi U W(t)
$$

$\xi:$ 水使用増加係数

$$
U W(t)=\sum U W_{c}(t)
$$

$c$ : ソウル, 仁川, 京畿道

$$
\begin{gathered}
U W_{c}(t)=U W_{c}^{H}(t)+U W_{c}^{I}(t)+U W_{c}^{A}(t) \\
U W_{c}^{H}(t)=\sum P_{n} \times U W_{-} P H \\
U W_{c}^{I}(t)=\sum I_{n} \times U W_{-} P I \\
U W_{c}^{A}(t)=\sum A_{n} \times U W_{-} P A
\end{gathered}
$$

$U W_{c}^{H}(t)$ : 家庭からの水使用量 $U W_{c}^{I}(t)$ : 産業からの水使用量

$U W_{c}^{A}(t)$ : 農業からの水使用量 $P_{n}$ : 世帯数 $I_{n}$ : 総生産額 $A_{n}$ : 農地面積

$U W_{-} P H: 1$ 世帯が 1 年間消費する水量

$U W \_P A$ : 農作物面積あたり 1 年間消費する水量

$U W \_P I:$ 製品 1 ウォンを生産するために消費する水量

‡日本の污濁物質原単位を利用

$\S$ 日本の污濁物質原単位を利用 
（2）水利用負担金の運用

$$
T W(t)=C E E(t)+C E M(t)+C P L(t)+C O(t)
$$

$C E E(t)$ : 環境基礎施設の設置費 $C E M(t)$ : 環境基礎施設の運営費 $C P L(t)$ : 土地の買収費 $C O(t)$ : そのほかの費用（産業に対する補助金）

\subsection{3 経済モデル}

（1）生産物市場のフロー

$$
X_{i}(t) \geq A_{i} \sum x_{i}(t)+C_{i}(t)+i^{P}(t)+i^{k}(t)+B^{s}\left(i^{1}(t)+i^{2}(t)\right)+B^{c}\left(\delta \Delta z^{3}(t)\right)+e(t)
$$

$X_{i}(t)$ : 産業別生産額 $A_{i}$ : 投入産出係数 $\quad C_{i}(t)$ : 消費係数

$i^{P}(t)=\sum_{i} i_{i}^{p}(t) \quad$ 流域での生産投資 $\quad e(t)$ : 純輸出

$i^{k}(t)=\sum_{i} i_{i}^{k}(t) \quad$ 流域での下水道, マウル下水道への投資合計

$B^{s}, B^{c}$ : 下水道, マウル下水道, 合併処理浄化槽設置による各産業への生産誘発係数 消費制約

$$
H \sum_{i} z_{i}(t) \geq C(t)
$$

$H$ : 産業別消費係数（一人当たりの産業別消費額）

移出制約

$$
e(t) \leq e_{\max }
$$

$e_{\max }$ : 純移出の上限 (純移出 $=$ 移出 $一$ 移入)

GRP（流域内総生産額）

$$
G R P(t)=\sum \mu_{i} X(t)
$$

$\mu_{i}$ : 産業別付加価値率 $\quad X(t)$ : 産業別総生産額

(2) 目的関数

$$
\operatorname{Max} \sum_{t=1} \frac{1}{(1+\rho)^{(t-1)}} G R P(t)
$$

$\rho:$ 社会的割引率 $(\rho=0.05)$

Subject to

$$
Q(t) \leq Q^{*}(t)
$$

$Q(t)^{*}$ : 八堂湖流入污濁負荷目標值

\section{3. シミュレーション}

\section{1 シミュレーションケース}

シミュレーションは 2001 年のデータを基準に 2010 年比で削減目標を設定する。 


\begin{tabular}{|c|c|}
\hline Case & 区 分 \\
\hline Case 0 & 現状維持, 污濁物質制約なし \\
\hline Case $1-0$ & 政策実施, 污濁物質制約なし \\
\hline Case 1 & 政策実施，污濁物質制約あり \\
\hline
\end{tabular}

\subsubsection{Case 0 （現状維持, 污濁物質制約なし）}

研究対象地域で水利用負担金制度の現状が維持され，産業への補助金制度が実施されなかった と仮定した場合のシミュレーションを行った。

（1） GRP 及び污濁物質量

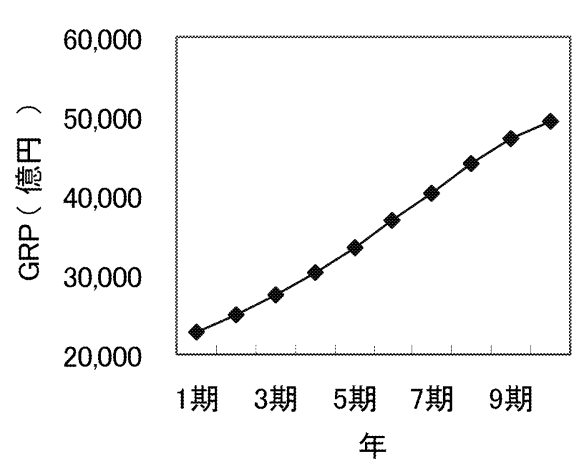

図 4 Case 0 GRP 推移

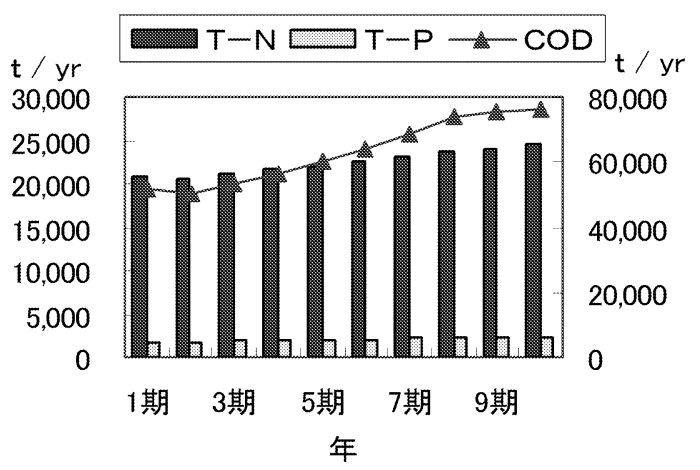

図 5 Case 0 污濁物質量推移

2010 年の各污濁物質量は 2001 年の污濁物質量に対し, $\mathrm{T}-\mathrm{N}$ は $118 \%$ 増, T $-\mathrm{P}$ は $131 \%$ 増, COD は $146 \%$ 増になることが明らかになった。

(2) 水利用負担金

水利用負担金に関しては 2001 年の賦課額である水使用量 1 トン当たり 11 円を維持すると仮定 した場合，2010 年には 2,101 億円（10 年間蓄積）になると予測される。流域内総生産は 279,586 億円（10 年間蓄積）になると予測されることから，水利用負担金の流域内総生産での割合は $1 \%$ を占めることになる。

\subsubsection{Case 1-0（政策実施, 污濁物質制約なし）}

2001 年の污濁物質発生源別污濁負荷量のフレームに基づき, 提案した政策をモデルに組み込ん でシミュレーションした結果, 2010 年の污濁負荷量, T-N で 20,682トン/年, T-P は 1,797卜 ン/年, COD は52,099 トン/年となることがわかった。この結果を Case 1-0 と定義し,さらに污 濁物質制約をかけることを仮定し, Case 1 のシミュレーションを行う。

\subsubsection{Case 1 (政策実施, 污濁物質制約あり)}

Case 1-0 を基準值とし，そこから削減可能な污濁物質量を求めた。 
(1) GRP

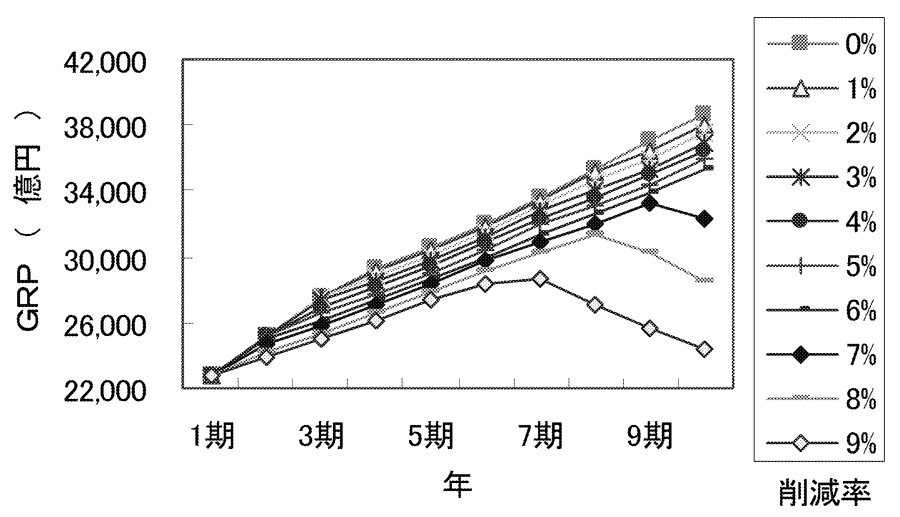

図 6 Case 1 削減率別 GRP 推移

污濁物質 $0 \%$ 削減（Case 1, 0\% 削減の対 2010 年比）時は GRP が 2001 年に比べ， $170 \%$ 増加 する反面, 污濁物質 $9 \%$ 削減 (Case 1, 0\% 削減の対 2010 年比) 時の GRP は 2001 年 GRP の 107\% しか成長できないことが明らかになった。削減可能な最大限の污濁物質量と GRP の最大化とい う観点から污濁物質 0\% 削減（Case 1，0\% 削減の対 2010 年比）から 6\% 削減（Case 1，0\% 削 減の対 2010 年比) を範囲として検討するのが妥当と考えられる。なお，污濁物質 $7 \%$ 削減 (Case 1，0\% 削減の対 2010 年比）時からは，GRP が減少するが，その理由としては，水質污濁物質の 削減のために，付加価值が高い産業の生産が減少するためと考えられる。

（2）污濁物質量

表 4 Case 1 污濁物質別 削減目標値及び結果

(10 期目, 単位 : $\mathrm{kg}$ )

\begin{tabular}{|r|r|r|r|r|r|r|r|}
\hline & & $1 \%$ 削減 & 2\% 削減 & 3\% 削減 & 4\% 削減 & 5\% 削減 & \multicolumn{1}{c|}{$6 \%$ 削減 } \\
\hline T-N & 目標值 & $20,578,360$ & $20,370,500$ & $20,162,630$ & $19,954,770$ & $19,746,910$ & $19,539,050$ \\
& 結 果 & $20,578,360$ & $20,370,500$ & $20,162,630$ & $19,954,770$ & $19,746,910$ & $19,539,050$ \\
\hline $\mathrm{T}-\mathrm{P}$ & 目標值 & $1,778,783$ & $1,760,815$ & $1,742,848$ & $1,724,880$ & $1,706,913$ & $1,688,945$ \\
& 結 果 & $1,778,783$ & $1,760,815$ & $1,742,848$ & $1,724,880$ & $1,706,913$ & $1,688,945$ \\
\hline COD & 目標值 & $51,577,800$ & $51,056,820$ & $50,535,830$ & $50,014,840$ & $49,493,850$ & $48,972,860$ \\
& 結 果 & $51,577,800$ & $51,056,810$ & $50,535,830$ & $50,014,840$ & $49,493,850$ & $48,972,860$ \\
\hline
\end{tabular}

污濁物質量において各污濁物質の削減目標值とシミュレーション結果から出された計算值を比 較すると，0\% 削減（Case 1，0\% 削減の対 2010 年比）時に窒素が削減目標值の $1 \%$ 達成できて いないこと, $2 \%$ 削減 (Case 1, 0\% 削減の対 2010 年比)には COD が削減目標值に達成できなかっ たこと以外はシミュレーション結果值が削減目標值を達成していた。 
（3）水利用負担金

表 5 Case 1 GRP の水利用負担金割合（10 年間蓄積）

(単位：億円)

\begin{tabular}{|c|r|r|r|r|r|r|}
\hline & $1 \%$ 削減 & $2 \%$ 削減 & 3\% 削減 & $4 \%$ 削減 & 5\% 削減 & 6\% 削減 \\
\hline GRP & 246,201 & 244,086 & 241,594 & 239,073 & 236,505 & 233,334 \\
\hline 補助金 & 25,119 & 24,589 & 22,897 & 23,835 & 23,383 & 26,289 \\
\hline 割合 & $10 \%$ & $10 \%$ & $9 \%$ & $10 \%$ & $10 \%$ & $11 \%$ \\
\hline
\end{tabular}

GRP における補助金の比率は $0 \%$ 削減（Case 1，0\% 削減の対 2010 年比）時の 9\% を除いて, $3 \%$ 削減（Case 1，0\% 削減の対 2010 年比）時に 9\%，6\% 削減（Case 1，0\% 削減の対 2010 年 比）時に $11 \%$ であり，3\% 削減（Case 1，0\% 削減の対 2010 年比）時にもっとも低い。

表 6 Case 1 削減率別 污濁負荷量削減対策費内訳（10 年間蓄積）（単位：百万円）

\begin{tabular}{|c|c|c|c|c|c|c|c|c|}
\hline & \multirow{2}{*}{ 生活排水補助 } & \multirow{2}{*}{ 土地利用補助 } & \multicolumn{5}{|c|}{ 生産額補助 } & \multirow{2}{*}{ 合 計 } \\
\hline & & & 農業 & 畜産業 & 水産業 & 製造業 & その他 & \\
\hline $0 \%$ 削減 & $1,835,839$ & 370,502 & 0 & 12,467 & 512 & 0 & 0 & $2,219,319$ \\
\hline $1 \%$ 削減 & $1,981,466$ & 397,971 & 36,670 & 95,765 & 0 & 0 & 0 & $2,511,873$ \\
\hline $2 \%$ 削減 & $1,864,854$ & 370,502 & 0 & 0 & 0 & 223,525 & 0 & $2,458,881$ \\
\hline $3 \%$ 削減 & $1,888,453$ & 296,951 & 104,179 & 0 & 121 & 0 & 0 & $2,289,704$ \\
\hline $4 \%$ 削減 & $1,898,708$ & 219,761 & 24,702 & 0 & 1,723 & 238,616 & 0 & $2,383,510$ \\
\hline $5 \%$ 削減 & $1,895,117$ & 443,162 & 0 & 0 & 0 & 0 & 0 & $2,338,279$ \\
\hline $6 \%$ 削減 & $1,847,111$ & 568,944 & 162,848 & 49,976 & 0 & 0 & 0 & $2,628,880$ \\
\hline
\end{tabular}

削減別に補助金の推移を見ると $0 \%$ 削減（Case 1，0\% 削減の対 2010 年比）と 5\% 削減（Case 1，0\% 削減の対 2010 年比) 以外は各污染源別に補助金が支給されることがわかった。よって，10 年後の削減目標値としては $3 \%$ 削減 (Case 1，0\% 削減の対 2010 年比) が最も妥当と考えられる。

\section{4. 結 果}

\subsection{1 年及び 2010 年のフレーム比較}

各污濁物質排出源別フレームを作成した。シミュレーション（表 7）によると，2001 年の生活 系人口は 3,973,507 人であり, 2010 年(なし), 2010 年 (3\%)の 4,827,391 人を比較した場合, 2010 年の人口は 2001 年の 2 倍以上増える。また, 2001 年の下水道普及率 (下水道 2,065,124 人, マウ ル下水道 63,905 人，合併処理 225 人の合計の総人口に対する割合）は $54 \%$ だったが，2010 年の 下水道普及率 (下水道 $3,055,534$ 人, マウル下水道 564,784 人, 合併処理 225 人の合計の総人口に 対する割合)が $75 \%$ まで達する。面源系では畑は市街地や雑種地に変化する。そして，生産系で 
は污濁負荷量が高い畜産業，水産業の生産額が減り，付加価值が高い製造業やその他の産業への 生産額が高くなることが明らかになった。

表 72001 年及び 2010 年 発生源別フレーム比較

\begin{tabular}{|c|c|c|c|c|c|}
\hline \multirow[b]{2}{*}{ 発生源 } & & \multicolumn{3}{|c|}{ フレーム } & \multirow[b]{2}{*}{ 単位 } \\
\hline & & 2001 年 & 2010 年（なし） & 2010 年 $(3 \%)$ & \\
\hline \multirow[t]{7}{*}{1 生活系 } & 下水道 & $2,065,124$ & $2,842,013$ & $3,055,534$ & 人 \\
\hline & マウル下水道 & 63,905 & 0 & 564,784 & 人 \\
\hline & 合併処理 & 225 & 778,530 & 225 & 人 \\
\hline & 単独処理 & 685,560 & 470,296 & 571,869 & 人 \\
\hline & し尿処理施設 & $1,158,693$ & $1,248,826$ & 634,979 & 人 \\
\hline & 生活雑排水未処理 & $1,844,253$ & $1,719,122$ & $1,206,848$ & 人 \\
\hline & 計 & $3,973,507^{* *}$ & $4,827,391^{\dagger+}$ & $4,827,391^{\text {柑 }}$ & 人 \\
\hline \multirow[t]{6}{*}{2 面原系 } & 農地（水田） & 201,666 & 0 & 201,666 & ha \\
\hline & 農地（畑） & 169,218 & 0 & 126,457 & ha \\
\hline & 山林 & $1,787,372$ & $1,787,372$ & $1,787,372$ & ha \\
\hline & 市街地 & 29,575 & 641,719 & 144,342 & ha \\
\hline & 雑種地 & 241,260 & 0 & 169,254 & ha \\
\hline & 計 & $2,429,091$ & $2,429,091$ & $2,429,091$ & ha \\
\hline \multirow[t]{6}{*}{3 生産系 } & 農業 & 215,083 & 507,154 & 301,425 & 百万円 \\
\hline & 畜産業 & 96,452 & 227,430 & 67,517 & 百万円 \\
\hline & 水産業 & 861 & 2,030 & 603 & 百万円 \\
\hline & 製造業 & $3,024,523$ & $7,131,690$ & $7,131,690$ & 百万円 \\
\hline & その他産業 & $2,238,695$ & $4,479,552$ & $2,640,690$ & 百万円 \\
\hline & 計 & $5,575,615$ & $12,347,856$ & $10,141,926$ & 百万円 \\
\hline
\end{tabular}

\section{2 ケース別 GRP 及び污濁物質量}

まず，ケース別に GRP を比較してみると, 2001 年の現状を維持し, 污濁物質排出の制約をかけ なかった場合, 2010 年には, 2001 年に比べて約 2.5 倍成長することが明らかになった。しかし, 污 濁物質制約をかけずに，污濁物質削減政策だけを実施する場合や污濁物質制約を $3 \%$ かけた上で 污濁物質削減政策を実施する場合も，2010 年の GRP は約 2 倍（2001 年比）成長させることがで きることが明らかになった。 


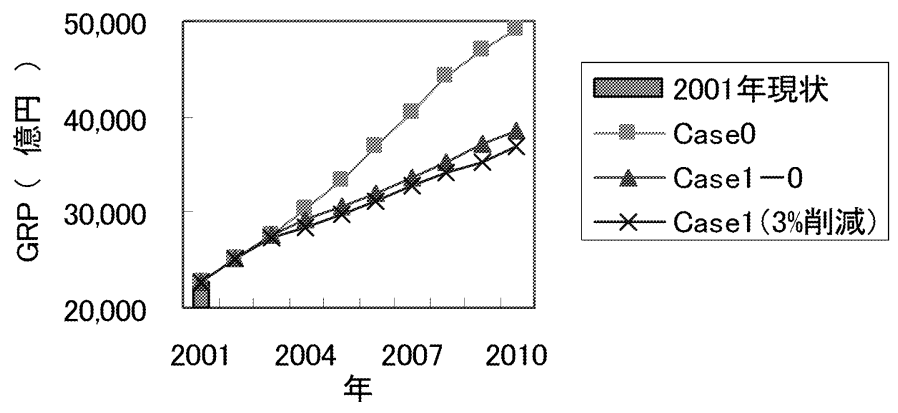

図 72001 年及びケース別 GRP 比較

次に,ケース別に污濁物質量の推移を比較した。10 年間現状維持された Case 0 と污濁物質削減 の制約がないCase 1 の場合を比較すると，それぞれ污濁物質において，窒素 $16 \%$ ，リン $23 \%$ ， $\mathrm{COD}$ は $31 \%$ 削減可能であることが明らかになった。また, 10 年間現状維持された Case 0 と $3 \%$ 削減（Case 1，0\% 削減の対 2010 年比）と比較した場合は，窒素は 18\%，リンは 26\%，COD は $33 \%$ 削減可能であることが明らかになった。

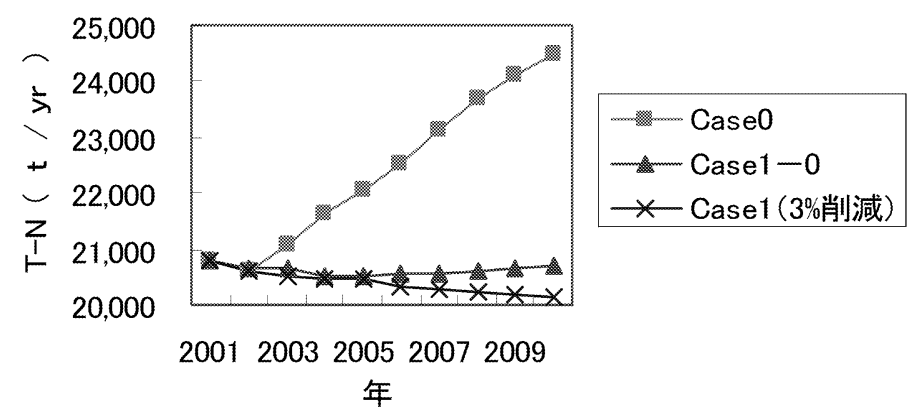

図 8 ケース別 $\mathrm{T}-\mathrm{N}$ 比較

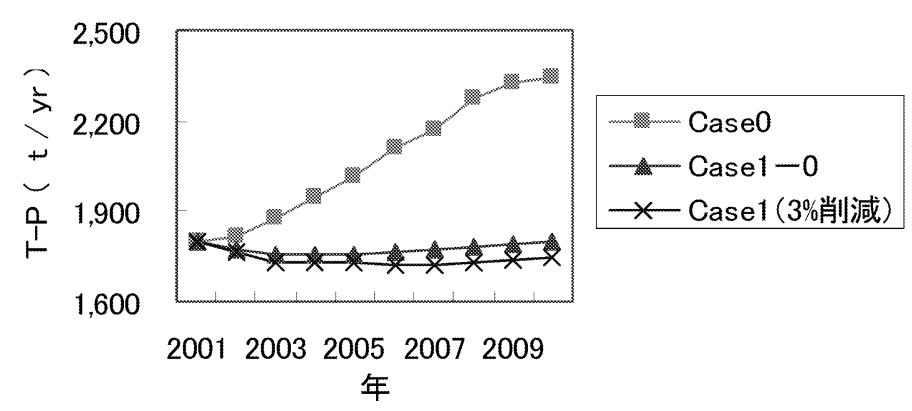

図 9 ケース別 $\mathrm{T}-\mathrm{P}$ 比較 


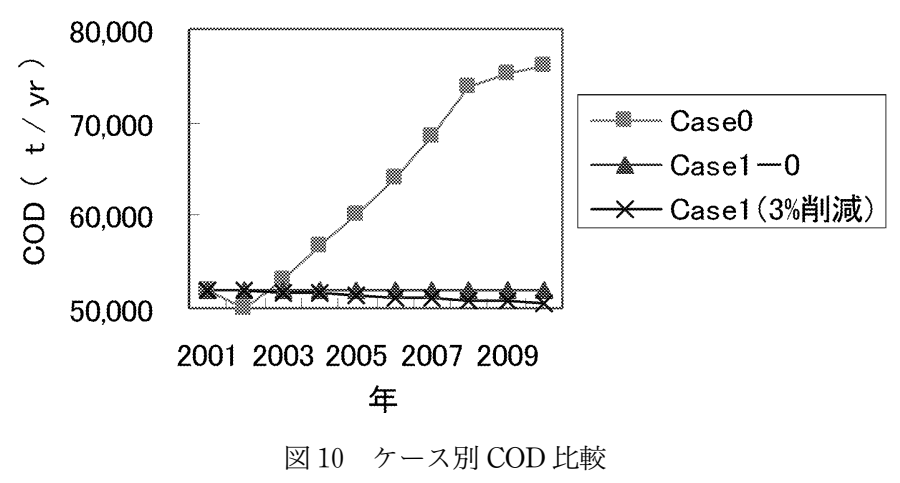

\section{3 水利用負担金}

表 $83 \%$ 削減 (Case 1, 0\% 削減の対 2010 年比）水利用負担金の污染源 別配分 (単位：億円，10 年間蓄積）

\begin{tabular}{|l|r|r|r|}
\hline \multicolumn{1}{|r|}{ 流域 } & 生活系 & 面源系 & 生産系 \\
\hline 南漢江 & 16,048 & & \\
\cline { 1 - 2 } 北漢江 & 1,478 & 29 & 1,043 \\
\cline { 1 - 2 } 漢江流域 & 1,357 & & \\
\hline
\end{tabular}

シミュレーションによると，污濁物質 3\% 削減 (Case 1，0\% 削減の対 2010 年比) の場合，そ れぞれ流域別に 1 年間におおよそ 2,000 億円の水利用負担金がかかる。この金額は 2001 年の水利 用負担金の総額の 100 倍になる。

\section{5. 結 論}

シミュレーションにより, 2010 年の合理的な排出可能污濁物質量を求めた結果, 窒素は $55 \mathrm{t} / \mathrm{d}$, リンは $4 \mathrm{t} / \mathrm{d}, \mathrm{COD} は 138 \mathrm{t} / \mathrm{d}$ であった。シミュレーション上で，それぞれケースでの 2010 年の 污濁物質削減量を比較した結果, 窒素はリンや COD に比べ, 削減しにくいが, 各污濁物質が削減 目標值を達成していることから，本研究で提案した政策がすべての污濁物質を削減するのに有効 であることが示唆された。また，污濁物質 3\% 削減 (Case 1，0\%削減の対 2010 年比) を達成す るために水利用負担金は 10 年間で下水道, マウル下水道, 合併浄化槽の設置, 運営に 18,885 億円 (10 年間蓄積), 土地の買収には 29 億円 (10 年間蓄積), 生産系には 1,043 億円 (10 年間蓄積) の 補助金を投入する必要があることがわかった。なお，この金額を 1 年間で必要とされる水利用負 担金に換算すると 2001 年の水利用負担金の 100 倍の金額であった。

本研究では，現在水利用負担金が配分されている地域の中で特に水利用負担金の配分が必要と される周辺地域や規制地域に重点をおくと提案した上でシミュレーションを行った。シミュレー ションにより水利用負担金の配分地域を規制地域及び周辺地域に限定し，規制地域住民の不満を 
解消するために産業への補助金を出す政策は有効であることが明らかになった。しかし，現在の 水利用負担金の賦課額では補助金を賄うことができない。水利用量 1 トン当たり 11 円から 1,100 円に上げることが必要である。この提案された金額は，現状の水利用負担金が 2 年ごとに 2 円ず つ上がっていることに比べるとかなり大きい額になる。また，[14]によると首都圈市民から導出 した八堂湖の水質を改善するための支払い意思額は, 1 月に水使用量 1 トン当たり 120 円から 174 円であることが確認されている。それに比べて本研究で提案した金額は大きいため，より現実的 な提案のためには空間的提案及び対策的提案を修正する必要がある。

\section{6. 今 後の 課 題}

八堂湖は他の污濁物質量に比べ, 窒素の污染度が高かった。その原因を明らかにし, 窒素削減 のための政策を提案し，その効果を検討する研究が必要とされる。また，本研究で提案した金額 がかなり大きいため，より現実的な提案にするためには空間的提案か対策的提案を修正する必要 がある。

\section{参考文 献}

［1］忠清北道『忠清北道統計年鑑』, 2001 年.

[2 ］ 江原道『江原道統計年鑑』, 2001 年.

[3 ] 京畿道『京畿道統計年鑑』, 2001 年.

[4] 京畿開発研究院·韓国環境政策評価研究院, “八堂湖上水源水質改善及び住民の生活質の向上に関する研 究最終報告会”，2004 年.

[ 5 ] 広瀬史明, “霞ヶ浦流域における流入污染負荷削減のための環境政策”, 筑波大学環境科学研究科修士論 文, 2001 年.

［6］氷鉋揚四郎, “霞ヶ浦環境改善総合評価政策モデル”, 草稿, 1984 年.

[7] Higano, Yoshiro and Sawada, Takayuki, "The Dynamic Optimal Policy to Improve the water Quality of Lake Kasumigaura”, 『地域学研究』Vol. 26(1), 1997 年, pp. 75-86.

[8］漢江流域環境庁『漢江水系 環境統計便覽』, 2001 年.

[9] 韓国銀行『2000 年産業連関表』, 2003 年.

[10] Kim, Lee-Hyung and Choi, Euiso, "Phosphorus release rates from sediments and pollutant characteristics in Han River, Seoul, Korea, "Science of The Total Environment," Volume 321, 2004, Issues 1-3, pp. 115-125.

[11］水野谷剛, “霞ヶ浦水質改善のための污濁負荷削減技術評価と最適環境政策に関する研究”, 筑波大学大 学院生命環境科学研究科生物圈資源科学専攻博士（学術）学位論文, 2002 年.

[12］環境部『八堂湖など漢江水系上水源管理特別総合対策，きれいな漢江』，1998 年.

[13] Ministry of environmental, "Implementation of a Watershed Management system : Four Major River Basins," Issue 2, Volume I, 2003.

[14] ソンミヨン『漢江水系水利用負担金の効果的運営方案』京畿開発研究院，2000 年. 


\title{
A Study for the Effective Management of Water-Use Charge System in order to Reduction of Water Pollutant in Paldang Lake, Korea
}

\author{
Jinjoo KIM* and Yoshiro Higano*
}

Paldang Lake has been working as water supply source for the capital Seoul in South Korea and metropolitan area. From geographical features, Paldang Lake has high density of eutrophication material such as phosphorus and nitrogen. And increase of population and development of economy has made water quality deteriorate. Moreover, surrounding area of Paldang Lake cannot be developed from various restrictions by government. Then, resident's dissatisfaction is not improved though the government executed the water quality improvement policy in 1999. And the improvement of the water quality is not yet seen. The government collects 11 yen per ton as the water use charge. But, the distribution of the fund is inappropriate.

In this study, we formulate a model which describes socio-economic activities, land use and the load of pollution (nitrogen, phosphorus, COD) and suggest effective policies in order to reduce pollution. First proposal is the region which distributed water-use charge is decreased. And, second proposal is the government subsidize for industries of restricted region. We simulate the model which can promote a sustainable development of Paldang area from the year 2001 to 2010.

In conclusion, GRP will increase twice in ten years. Amount of nitrogen, phosphorus, COD's exhaust becomes $55(\mathrm{t} / \mathrm{d}), 4(\mathrm{t} / \mathrm{d}), 138(\mathrm{t} / \mathrm{d})$. And it compared with the case of no execution of the policy, nitrogen, phosphorus, COD is reduced by $18 \%, 26 \%$, and $33 \%$. And, 11 yen per ton for the water supply of 2001 is needed to be raised to 1,100 yen a ton for the policy execution. It was confirmed that the policy proposal in this study is effective. A distribute of fund and the subsidy for industries in the restriction region is effective to reduce the pollution.

JEL classification: Q53, C61, Q58

Keywords: water pollution, Optimization Analysis, Government policy

* University of Tsukuba 